\title{
An Inquiry into Islamic Finance from the Perspective of Sustainable Development Goals ${ }^{1}$
}

\author{
Ahmet Suayb Gundogdu*
}

\begin{abstract}
Of the 17 Sustainable Development Goals (SDGs) of the United Nations, the first 11 relate directly to Islamic economics and finance. Indeed, they are a perfect fit with the purpose and principles of Islamic finance. Moreover, the Islamic finance industry has contemporary products to address these SDGs. This paper presents current product development and implementation examples of Islamic finance in the context of SDGs. In this regard, success with SDGs can be attained through resource mobilization. Reality suggests that such mobilization requires product development and successful SDG programs. Further, in order to attract resources, SDG programs need to provide convincing results. The most effective programs, as presented in this paper, should be financed with suitably employed resource mobilization tools. Islamic finance can address the first 11 SDGs by harnessing modern resource mobilization products to these programs.
\end{abstract}

Keywords: Sustainable Development Goals (SDGs), Micro Finance, SME Financing, Infrastructure Development, Affordable Housing, International Trade, Complementary Currency, Cash Waqf, Zakat, Economic Empowerment Fund, Crowd Funding.

\section{Introduction}

The Sustainable Development Goals (SDGs) of the United Nations have attracted the attention of Islamic finance practitioners and scholars. The reason is that the goals are perfectly aligned with the philosophy of Islamic finance [12]. Zarrouk reflected on the role of Islamic finance as a novel finance alternative in the context of SDGs [12]. He highlighted the profit-loss sharing arrangement of Islamic finance, its solidarity-based feature for poverty alleviation, and its use of sukuk for resource mobilization to finance infrastructure development. In the context of SDGs, Ahmed et al. explored the potential of Islamic financial institutions and capital markets to address the vulnerability of the poor, financial stability, and development [2]. As highlighted by Ahmed et al, the critical issue for achieving SDGs, namely the developmental agenda for 2015-2030, is resource mobilization [2]. The SDG programs to achieve the given targets require unprecedented resource mobilization compared with their predecessors, the programs of the Millennium Development Goals, which focused on a limited number of targets. Thus, it is important to have an inquiry into Islamic finance's role in supporting the resource mobilization efforts for SDGs. The academic research in this area offers

${ }^{1}$ The Economic Empowerment and Islamic Microfinance parts of the work is based on extensive product development and implementation experience of Mr. Abdelaziz Slaoui Andaloussi from Islamic Development Bank. 
limited insights because there has been little opportunity for scholars to obtain hands-on experience of the practice of Islamic developmental finance. This study's aim is to bridge the gap between academic research and hands-on real-life practice.

The practice of Islamic social investment suggests that the best approach to achieve SDGs is by harnessing the right blend of resource mobilization tools, namely grants, concessional loans, and commercially priced loans, with the most effective programs. It is most important to match SDG programs with correct resource mobilization methods and platforms. Unfortunately, academic proposals for the harnessing of zakat, waqf, and qarz-e hasan fail to consider real-life implications. Table 1 proposes and tabulates current systems and appropriate Islamic resource mobilization interventions to undertake these SDG programs. The systems and interventions are based on real-life hands-on experience of Islamic developmental finance.

Table 1. Matching resource mobilization with SDGs and their programs

\begin{tabular}{|c|c|c|c|}
\hline \multicolumn{2}{|c|}{ Proposed Islamic Resource Mobilization } & \multirow{2}{*}{$\begin{array}{l}\text { SDGs } \\
\text { SDG \#1: Poverty }\end{array}$} & \multirow[b]{2}{*}{ 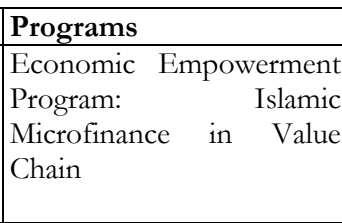 } \\
\hline \multirow[t]{2}{*}{$\begin{array}{l}\text { 1. Commercially Priced Loans: } \\
\text { Islamic Finance Modes (funds } \\
\text { returned from beneficiaries of } \\
\text { finance, principals plus market } \\
\text { markups, to fund providers) }\end{array}$} & \begin{tabular}{|l} 
Economic \\
Empowerment \\
Funds \\
Developmental \\
Waqf
\end{tabular} & & \\
\hline & $\begin{array}{l}\text { 1.Investment } \\
\text { Sukuk }\end{array}$ & $\begin{array}{lr}\text { SDG \#7: } & \text { Affordable } \\
\text { Energy } & \\
\text { SDG \#9: } & \text { Industrial } \\
\text { Innovation r } & \text { and } \\
\text { Infrastructure } & \\
\text { Development } & \\
\text { SDG \#8: Decent Work } \\
\text { and Economic Growth }\end{array}$ & $\begin{array}{l}\text { 1.Public Private } \\
\text { Partnership } \\
\text { 2. Small and Medium-sized } \\
\text { Enterprise Line of } \\
\text { Financing }\end{array}$ \\
\hline $\begin{array}{l}\text { 2. Grants: Zakat (direct transfer } \\
\text { of funds from the rich to the } \\
\text { poor; neither principals nor } \\
\text { markups go back to fund } \\
\text { providers) }\end{array}$ & Zakat Platform & $\begin{array}{l}\text { SDG \#2: Zero Hunger } \\
\text { SDG \#5: Gender } \\
\text { Inequality } \\
\text { SDG \#10: } \\
\text { Within and } \\
\text { Countries }\end{array}$ & $\begin{array}{l}\text { 1. Support for } \\
\text { Microfinance Beneficiaries } \\
\text { to Eradicate Hunger } \\
\text { 2. Wealth Distribution } \\
\text { Programs as Opposed to } \\
\text { Social Transfer, Food } \\
\text { Stamps, and Social Security } \\
\text { Systems }\end{array}$ \\
\hline $\begin{array}{l}\text { 3. Concessional Loans: Qarz-e } \\
\text { Hasan (funds returned with } \\
\text { principals plus market markups; } \\
\text { markups spent on programs for } \\
\text { beneficiaries, with the principals } \\
\text { returned to the fund providers) }\end{array}$ & \begin{tabular}{|l|} 
Complementary \\
Currency \\
Crowd funding \\
Cash Waqf/Cash \\
Waqf Sukuk \\
\end{tabular} & $\begin{array}{l}\text { SDG \#3: Health } \\
\text { SDG \#4: Education } \\
\text { SDG \#6: Clean Water } \\
\text { and Sanitation } \\
\text { SDG \#11: Sustainable } \\
\text { Cities }\end{array}$ & $\begin{array}{l}\text { Flagship Programs Related } \\
\text { to Social Investment (listed } \\
\text { in Table 3) }\end{array}$ \\
\hline
\end{tabular}

Source: Author's work experience of Islamic developmental finance

The gist of the Islamic approach is to provide a blend of resources to encourage cooperation among the active poor as opposed to competition in a zero-sum game. The aim is to generate value addition in value chains. In this regard, it is best to tackle the issue of poverty in rural areas before such poverty migrates to urban areas. In the latter, poverty can become unmanageable because migrants may not develop the skills that are needed to add value in an urban economy. As highlighted by Wilson, experience shows 
that if a microfinance program is designed properly in terms of profit-loss sharing with farmers or Islamic loans, developmental activity is viable [11]. In particular, the group purchase of input materials and the sale of products as a group give substantial bargaining power to farmers and microfinance institutions. It is then possible to achieve high profit margins. In such cases, an economic empowerment fund can help to alleviate poverty still further.

\section{Commercially Priced Loans (Islamic Finance Modes)}

In the first category of resource mobilization proposals, commercially priced loans (see Table 1), the funds returned to fund providers by beneficiaries/borrowers consist of the principals plus the market markups. The purpose of such loans is to create an enabling environment through financial inclusion. Unlike the proposal of Elgari (2004), who suggested interest-free loans (qarz-e hasan) to the poor, the returns of commercially priced loans are based on market rates to assure value addition for the investments. ${ }^{2}$ Further, as a finance strategy to generate economic activity, grants and concessional loans mislead an economy and allocate resources to inefficient transactions. In order to assure value addition, such programs should be used with market rates. Contrary to the commonly held belief, poor people can be a source of sustainable economic growth if they are endowed with an enabling environment. Economic empowerment is an integrated approach of Islamic finance that excludes no one. Its purpose is to invest with the poor and undertake economic activities, using Islamic financing formats, with low-income marginalized groups, unemployed youth, and productive families.

The concept of economic empowerment has been applied in more than one country and yielded very encouraging results. ${ }^{3}$ It is more profitable and less risky for all parties: fund providers, fund users, and communities. It is very effective at combatting poverty and achieving social security and development because its economic projects are more stable and resistant. The basis of the concept is that fundamental barriers exist that must be lifted to help eradicate poverty and integrate the poor into value chains so that they can achieve self-sustenance. Accordingly, economic empowerment through Islamic microfinance assumes that the essential need of the poor is multidimensional. In other words, poverty has several facets and financing is just one of them. Poverty has more to do with the inability to take advantage of project opportunities, economies of scale to compete with large producers, networks for market access, fair price formation, and, most importantly, supportive infrastructures. ${ }^{4}$

\footnotetext{
${ }^{2}$ Elgari, M. A. (n.d.) The Qard Hasan Bank. Mimeo. Available from the author.

${ }^{3}$ The Islamic Development Bank's results have been impressive for Palestine, Sudan, Yemen, Kazakhstan, and Benin.

4 A supportive infrastructure involves the creation and supply of economic zones, industrial zones, warehouses, generators, water purification units, incubators, packaging centers, laboratories, and other projects that cannot be provided by one initiative but can be achieved within the framework of unions, cooperatives, and solidarity groups. One of the objectives of these supportive projects is to ensure that initiatives for the economic empowerment of the poor have the same chance of success as large and medium enterprises in the private sector.
} 
Economic empowerment is indeed an Islamic microfinance program; yet it is not called Islamic microfinance for several reasons. The philosophy behind the concept is to address problematic issues with microfinance, whether such finance is Islamic or conventional. Unfortunately, though, microfinance lending programs very often defeat their purpose. Poor people become worse off because Microfinance Institutions (MFIs) run businesses for profit once the system proves that they are viable. MFIs prey on the poor by lending money without considering value addition in enterprises and by fueling competition in communities. In some instances, MFIs charge up to $200 \%$ interest by subtle deceit. For example, they ask for US $\$ 1$ return per day, compounding such a repayment until it reaches $200 \%$ interest per annum. The financially illiterate poor do not understand such a calculation [10].

In order to generate value addition for the poor, the economic empowerment concept focuses on value chains and encouraging group cooperation rather than competition. Experience shows that the agricultural sector supports value addition; however, the informal urban employment sector, which fuels zero-sum game competition, does not. MFIs adopt microfinance beneficiaries as business partners, buy agricultural input goods for all farmers at a discounted price, and act as off-takers during harvests in order to sell the farmers' produce in bulk for higher prices. Such an approach can generate a $20 \%$ margin for input purchases and a 20\% margin for the sale of harvests. The farmers are no longer susceptible to exploitation because of such intervention. For this reason, by participating in microfinance programs, farmers are better off. Even after paying a 15\% markup on financing, they still have a $25 \%$ margin. Besides, the concept has ancillary benefits such as group training and bulk storage. Indeed, this model can be expanded to other supportive infrastructures in order to support value chains. Further, microfinance programs can be supported by zakat to avoid the use of microfinance loans by farmers for food. The use of loans for food is one of the main reasons why microfinance interventions fail. The poor very often spend microfinance loans on food out of desperation. We should not blame them if they use money from loans to prevent their children starving when no other money is available. Thus, the poor default on their loans and are punished for the rest of their lives by financial institutions refusing them further access to funds. With the concept of economic empowerment, such drawbacks are addressed with zakat money, if needed, in order to assure that farmers can have food; thus, the farmers use their loans solely for their enterprises. However, unlike Kahf's proposal for the Diwan al Zakat to lend qarz-e hasan to farmers, zakat must be used in its traditional context and not for insuring farmers or bailing them out [8]. Experience has shown that after farmers become aware that the origin of their resources is zakat, or there is a possibility of a bailout with zakat money, they tend to default or present a default case. ${ }^{5}$

An economic empowerment fund represents resource mobilization in a cash waqf format. Cizakca, Ahmed, and Kafh proposed the use of the cash waqf concept for Islamic MFIs $[3,1,8]$. More recently, Haneef et al. developed an integrated waqf-based Islamic microfinance design in Bangladesh as a means to alleviate poverty [4]. Resources

\footnotetext{
${ }^{5}$ In the case of microfinance provided by the Islamic Development Bank through the Bank of Khartoum, the initial success of agricultural microfinance faded once the farmers were informed that the resource was zakat.
} 
mobilized under an economic empowerment fund are invested in microfinance but with a commercial return. The purpose is to create a snowball effect that enables the poor to access finance, with ring fencing through discounted input prices, fair harvest prices, and micro takaful. Ultimately, the poor become business partners who can add value if they are directed properly and have equal opportunities to compete against sizeable firms. Table 2 presents a comparison between traditional microfinance and Islamic microfinance based on economic empowerment.

Table 2. Classic microfinance as opposed to Islamic microfinance based on the economic empowerment concept

\begin{tabular}{|l|l|}
\hline Classic Microfinance & $\begin{array}{l}\text { Microfinance Based on the Approach of Economic } \\
\text { Empowerment }\end{array}$ \\
\hline $\begin{array}{l}\text { The Fundamental Need is for } \\
\text { Finance }\end{array}$ & $\begin{array}{l}\text { There are several basic needs: access to project opportunities, } \\
\text { access to partnerships, access to basic infrastructures, access to } \\
\text { financing, and access to markets. }\end{array}$ \\
\hline $\begin{array}{l}\text { The Marginalized or Poor Individual } \\
\text { is a Credit Borrower }\end{array}$ & $\begin{array}{l}\text { The marginalized or poor individual is a business partner who has } \\
\text { great potential for generating wealth. }\end{array}$ \\
\hline $\begin{array}{l}\text { Gains From Transactions With the } \\
\text { Poor are Made Even When the Poor } \\
\text { Suffer }\end{array}$ & $\begin{array}{l}\text { The practice followed is that of participatory finance: gains are } \\
\text { made from transactions with the poor but solidarity with the latter } \\
\text { remains. } \\
\text { Ethical finance is practiced; thus, ethical rules are followed. }\end{array}$ \\
\hline $\begin{array}{l}\text { Individual Micro-project } \\
\text { Microfinancing }\end{array}$ & $\begin{array}{l}\text { Micro-projects, medium projects, integrated projects, small and } \\
\text { medium-sized enterprises, large projects, micro/small/large } \\
\text { financing. }\end{array}$ \\
\hline MFIs Undertake the Financing & MFIs are socioeconomic actors. \\
\hline $\begin{array}{l}\text { MFIs Operate With Short-term } \\
\text { Clients }\end{array}$ & $\begin{array}{l}\text { MFIs conduct business with their clients in the short, medium, and } \\
\text { long terms depending on the projects' natures. }\end{array}$ \\
\hline The Clients Manage Their Projects & $\begin{array}{l}\text { MFI supports customers with the management of their projects } \\
\text { until the customers become autonomous. }\end{array}$ \\
\hline MFIs Manage the Financing & $\begin{array}{l}\text { MFIs manage the value chains in collaboration with a network of } \\
\text { specialized partners. }\end{array}$ \\
\hline Microcredit & $\begin{array}{l}\text { Financial engineering with different appropriate Islamic financing } \\
\text { methods that ensure projects' profitability. }\end{array}$ \\
\hline
\end{tabular}

Source: The fieldwork of Abdelariz Slaoui Andaloussi

Economic empowerment funds are established for the purpose of investing with the poor on a commercial basis. In this regard, the concept is similar to developmental waqf. Waqf is an endowment that has great potential for social welfare. Traditionally, such charitable endowments are usually in the form of land and real estate. However, waqf in the form of cash is also allowed. If established by cash endowment with the provision of supporting the poor, such waqf is called cash waqf $[7,8]$. Unlike traditional cash waqf, which is invested in the bankable projects of an organized sector and the returns then used for the poor, developmental waqf is invested in a portfolio of bankable and unbankable projects from the unorganized sectors of the poor.

When this approach to invest directly with the poor in viable opportunities is adopted, the impact on poverty alleviation multiplies because the returns from such investments are also spent on the poor. Economic empowerment fund resources are composed of developmental waqf paid in-capital, donor countries, national financial institutions, international financial institutions, corporate social responsibility programs, and zakat. 
From the perspective of Islamic principles, however, zakat should not be used as such because it is required to be a direct transfer of wealth. Hence, zakat should directly be given from the rich to the poor.

In order to expand the impact on value chains, more needs to be done for the following.

SDG \#7: Affordable Energy

SDG \#8: Decent Work and Economic Growth

SDG \#9: Industrial Innovation and Infrastructure Development

Once again, in order to assure the allocation of resources and work effort to viable and value-adding projects, the market markup rate should be used for project proposals related to these three SDGs. Infrastructure development and affordable energy projects can be undertaken with istisna and/or ijara agreements under public-private partnership (PPP) initiatives. If employment and economic growth are to be achieved, small and mediumsized enterprises (SMEs) require support in the form of financial resources. In this regard, two-step murabaha is the most efficient tool for SME financing and resource mobilization. In order to increase the number of PPP projects, invested money can be collected, after repayment starts, by issuing investment sukuk whereby investors give lump sums to financiers. The latter can then embark on new projects immediately instead of waiting for full repayment at the end of a 15-20 year tenor. Thus, it is essential to involve private sector resources in order to bridge the investment gap. Such an approach may appear more expensive at first glance because PPP finance is costlier than public finance. Nevertheless, long-term cost-benefit analysis proves that cost efficiency in project production and maintenance after project completion makes PPP cheaper than public finance, regardless of the higher financing cost. Return on economic empowerment funds and economic empowerment programs can also support SDG \#7-8-9.

\section{Grant Resources (Zakat)}

In the second category of resource mobilization proposals, grant resources (see Table 1), funds are not returned from beneficiaries to fund providers. The main grant resource in Islam is zakat, which is an entitlement whereby the poor share the wealth of the rich. With regard to hunger and inequality, Islam prefers zakat, a wealth distribution mechanism, to sadaqa, which is almsgiving. Zakat is collected annually at a rate of $2.5 \%$ from the rich based on their net worth. Because it is collected annually from net worth, and not income, zakat not only addresses the issues of hunger and inequality; it also inhibits wealth accumulation among a very small number of people who would otherwise set exploitative prices as more factors of production accumulate under their control. If all the factors of production are gathered in the hands of a few, such people would determine prices based on monopolistic and oligopolistic price setting, which is good for them but not for the poor. Zakat addresses the issues of hunger and inequality with direct and indirect effects: (1) the transfer of wealth to unfortunate people in the form of a direct effect on hunger and inequality, and (2) a decrease in prices by impeding the accumulation of the factors of production in the hands of a few in order to alleviate hunger and inequality.

Sadaqa, almsgiving, is not proposed as a means to address poverty; nor is it proposed as a means to address hunger and inequality in Islamic countries. Sadaqa is acceptable only 
in cases of emergency in order to correct the consequences of dire situations that emerge abruptly. If a situation that involves hunger and poverty is protracted, people should exert effort to address such problems rather than encouraging the masses to become addicted to almsgiving, namely sadaqa. Such protracted circumstances of poverty, as outlined here, can be addressed with enabling environments that can be created from Islamic microfinance programs for which resources are mobilized with economic empowerment funds and developmental waqf.

Zakat is an entitlement of the poor and represents their share in the wealth of the rich. The zakat resource should not be kept or collected for developmental programs or invested for the poor. Zakat money should be given directly to the poor. Nevertheless, zakat can also be used to support economic empowerment programs. For example, people under pressure to feed their families use microfinance loans as emergency resources; thus, they cannot generate value addition with the loans that they receive. Hence, zakat should complement economic empowerment funds. If microfinance beneficiaries are also victims of hunger, they should be able to use zakat money to feed themselves while investing microfinance loans to develop their enterprises.

Zakat is the social safety net of Islam. It does not represent social transfer in the form of food stamps or a social security system; instead, it prefers the direct transfer of wealth from the rich to the poor. With such a feature, it can alone address the issues of hunger and inequality in communities. Unfortunately, though, zakat collection rates are unsatisfactory. Indeed, the issue of zakat collection has been the subject of academic studies. For example, Kahf reported that the zakat collection rate is only between 0.3$0.4 \%$ of gross domestic product (GDP) in Pakistan, Yemen, and Saudi Arabia [6]. Further, Shirazi et al.'s calculation showed that the maximum zakat collection rate ranges between 1.8-4.3\% of GDP annually with institutional arrangements [9]. People's lack of trust in zakat collection agencies and the lack of efficient collection channels may be two reasons for such low zakat collection levels.

\section{Concessional Resources (Qarz-e Hasan)}

In the third category of resource mobilization proposals, concessional loans (see Table 1), collected funds are invested and the generated markup is spent on SDG programs. Only the principal returns to the fund providers. As a general approach in Islam, an interest-free loan, qarz-e hasan, is better than a grant.

Who is it that would loan Allah a goodly loan so He will multiply it for him and he will have a noble reward? $(57: 11)$

Believers are encouraged, in many verses in the Quran, to give interest-free loans, qarz-e hasan, in order to address protracted problems and break vicious circles. In contrast, sadaqa is for emergencies. For this reason, the solution proposed by Islamic finance for some SDGs revolves around concessional loans, qarz-e hasan. However, proposals such as those of Iqbal and Mirakhor to use qarz-e hasan for microfinance, which seeks profitable value-adding activities, should not be considered [5]. The use of qarz-e hasan, from its traditional perspective, would create zombie developmental programs that are addicted to concessional loans. Besides, it is improper to address SDGs that relate to basic necessities with commercially priced loans that give rise to price bubbles and 
exploitation of the poor. Moreover, Zakat is a direct transfer of money that addresses the issues of hunger and inequality and should not be used in developmental programs to address the following SDGs.

SDG \#3: Health

SDG \#4: Education

SDG \#6: Clean Water and Sanitation

SDG \#11: Sustainable Cities

These SDGs should be addressed with concessional resources: qarz-e hasan from a new perspective. The traditional understanding of qarz-e hasan is to have the principal returned. However, the recipients of qarz-e hasan should not have any repayment obligation, thereby breaking the vicious circle of poverty. In many instances, the poor do not have the means for regular payments. They do not even have the US $\$ 100$ monthly installment toward the payment of the principal of qarz-e hasan for home ownership. The same holds for other social investment programs related to the foregoing four SDGs. Some of the flagship programs are listed in Table 3.

Table 3. Flagship programs related to social investment

\begin{tabular}{|c|c|}
\hline Program Name & Description \\
\hline $\begin{array}{l}\text { Basic Education } \\
\text { for the Poor }\end{array}$ & $\begin{array}{l}\text { The program's main objective is to provide access to free, quality, basic education } \\
\text { services for children in unserved, underserved, poor, and disadvantaged communities } \\
\text { by the following means: increasing retention; improving learning achievements; } \\
\text { increasing completion rates at primary level; and strengthening school management } \\
\text { structures. }\end{array}$ \\
\hline $\begin{array}{l}\text { Blindness } \\
\text { Control }\end{array}$ & $\begin{array}{l}\text { A partnership formed to address cataracts in less-developed countries (LDCs) and to } \\
\text { develop human resources in the ophthalmic field. }\end{array}$ \\
\hline $\begin{array}{l}\text { Coalition } \\
\text { Program to Stop } \\
\text { Obstetric Fistula }\end{array}$ & $\begin{array}{l}\text { The program supports the use of skilled birth attendance to prevent obstetric fistula. } \\
\text { Women with the condition directly benefit from treatment, rehabilitation, and } \\
\text { reintegration into society. }\end{array}$ \\
\hline $\begin{array}{l}\text { Drylands } \\
\text { Initiative }\end{array}$ & To bring sustainable development to pastoral and agropastoral communities. \\
\hline $\begin{array}{l}\text { Sustainable } \\
\text { Villages Program }\end{array}$ & $\begin{array}{l}\text { The program's primary objective is to reduce extreme poverty in the field with the help } \\
\text { of low-cost, sustainable, and community-led interventions. The program's scope } \\
\text { includes investment in sectors that directly relate to (i) agriculture and livestock, (ii) } \\
\text { primary education, (iii) primary health care, (iv) rural infrastructure, (v) business } \\
\text { development, (vi) the empowerment of women, and (vii) the preservation of the } \\
\text { environment with proper water and sanitation infrastructures. }\end{array}$ \\
\hline $\begin{array}{l}\text { Vocational } \\
\text { Literacy Program } \\
\text { for } \quad \text { Poverty } \\
\text { Reduction }\end{array}$ & $\begin{array}{l}\text { To improve the literacy competencies, job skills, and productivity of illiterate people } \\
\text { and the poor through access to nonformal education, vocational training, and/or } \\
\text { microfinance services. }\end{array}$ \\
\hline Affordable & $\begin{array}{l}\text { To use resources to subsidize monthly installment payments of the poor in order to } \\
\text { support the ownership of homes with clean water and proper sanitation. }\end{array}$ \\
\hline
\end{tabular}
Source: Islamic Solidarity Fund for Development

All these programs in Table 3 are related to basic human needs: health, education, and shelter. Experience shows that even non-interest bearing concessional loans do not enable the poor to make small monthly repayments to solve these problems. If the poor cannot solve these problems, they cannot integrate into global value chains and work to take care of themselves. First, we need to open the eyes of a blind person to enable him 
or her to work. The poor may not even be able to make the US\$100 installment payments required for an affordable housing program. The only solution is to mobilize resources with the concept of qarz-e hasan, invest the collected funds in commercially priced transactions, and use the profits to help the programs' implementation. Unfortunately, the general tendency is to keep zakat funds for such use. It is inappropriate to keep zakat money for investments with the poor. Zakat should be directly distributed to the poor. Thus, we should change our understanding of qarz-e hasan in order to use its resources for commercially priced SDG-related projects or investment sukuk. Such an approach would support developmental projects and employment, while the returns on qarz-e hasan can be used for supporting programs related to health, education, and shelter.

As stated earlier, the issues raised here concern human deprivation and have intangible aspects. Hence, from the maqasid perspective, the related programs should not be financed with commercially priced loans. In addition to return on Economic Empowerment Funds, innovative resource mobilization tools with qarz-e hasan should be employed to fund the programs. Returns on Economic Empowerment Funds' and qarz-e hasan funds' commercially priced investments should be used for health, education and shelter programs. The best resource mobilization tools to collect qarz-e hasan are complementary currency in microfinance, crowdfunding, cash waqf, and cash waqf sukuk.

Money collected with these instruments can be invested in economic empowerment funds, developmental waqf funds, investment sukuk, and two-step murabaha for commercial returns. The profits can be used to help run programs for health, education, and proper shelter without generating additional burdens on the poor, who can then focus on self-sustenance.

\section{Evaluation and Conclusion}

This systematic inquiry into Islamic finance for SDGs suggests that the perfunctory understanding of zakat and qarz-e hasan should change. Zakat, which addresses hunger and inequality, should be directly transferred from the net worth of the rich to the poor. It should not be withheld in the accounts of zakat institutions under the pretext of investing the money for the benefit of the poor. Qarz-e hasan, rather, should be withheld in the accounts for investing in mobilized resources for the benefit of the poor. The returns on qarz-e hasan investment should be used to provide support in the form of education, health, and shelter for the poor. Sadaqa should not be part of SDGs because it should only be used for emergency interventions in dire situations that occur occasionally. Protracted issues related to poverty and employment should be addressed by Islamic finance that seeks commercial returns and by focusing on value chains. While addressing value addition with Islamic microfinance through the economic empowerment concept, supportive infrastructure investment, such as in transport and energy, should also be identified to improve value chains. Such infrastructure development can be undertaken with istisna contracts, ideally in accordance with the PPP business model. Employment opportunities in downstream value chains should also be expanded through Islamic SME financing with two-step murabaha. At a strategic 
level, commercially priced loans, grants, and concessional loans should be harnessed to relevant SDGs. Further, the use of information and communications technology (ICT) platforms for resource mobilization, such as crowdfunding, will increase resource mobilization possibilities. However, the key is appropriate governance for the success of resource mobilization. Thus, resource mobilization platforms should be regulated and the rights of fund providers should be protected within a sound legal and risk management system. Fund providers should have assurances about the proper use of funds without any possibility of corruption or mismanagement.

\section{References}

Ahmed, H. (2011). Waqf-based microfinance: Realizing the social role of Islamic finance. In K. Monzer and M. M. Siti (Eds), Essential Readings in Contemporary Waqf Issues, CERT, Kuala Lumpur, 205239.

Ahmed, H., Mohieldin, M., Verbeek, J., and Aboulmagd, F. (2015). On the sustainable development goals and the role of Islamic finance. World Bank Policy Research Working Paper No. 7266. Available at SSRN: https://ssrn.com/abstract=2606839.

Cizakca, M. (2004). Cash waqf as alternative to NBFIs Bank. Paper presented at the International Seminar on Nonbank Financial Institutions: Islamic Alternatives, jointly organized by Islamic Research and Training Institute, Islamic Development Bank, and Islamic Banking and Finance Institute Malaysia, Kuala Lumpur, March 1-3.

Haneef, M. A., Pramanik, A. H., Mohammed, M. O., Amin, M. F. B., and Muhammad, A.D. (2015). Integration of waqf-Islamic microfinance model for poverty reduction: The case of Bangladesh. International Journal of Islamic and Middle Eastern Finance and Management, 8(2), 246270. https://doi.org/10.1108/IMEFM-03-2014-0029.

Iqbal, Z. and Mirakhor, A. (2007). Qard hasan microfinance (QHMF). Retrieved on April 2, 2009 from http://www.newhorizonislamicbanking.com/index.cfm?section=academicarticles\&action=view\&i $\mathrm{d}=10461$.

Kahf, M. (1999). Zakah: Performance in theory and practice. Paper presented at the International Conference on Islamic Economics Towards the 21st Century, Kuala Lumpur, August 1999.

Kahf, M. (2000). al Waqf al Islami, Tatawnuruh, Idaratuh, Tanmiyatub (Islamic waqf, its growth, management and development). Damascus: Dar al Fikr.

Kahf, M. (2004). Shari'ah and historical aspects of zakat and awqaf. Background paper prepared for the Islamic Research and Training Institute, Islamic Development Bank

Shirazi, N. S., Amin, M. F. B., and Anwar, T. (2009). Poverty elimination through potential zakat collection in the OIC-member countries: revisited. The Pakistan Development Review, 48)4), 739-754.

Sinclair, H. (2012). Confessions of a Microfinance Heretic: How Microlending Lost Its Way and Betrayed the Poor. Berrett Koehler Publishers: San Francisco, USA.

Wilson, R. (2007). Making development assistance sustainable through Islamic microfinance. IIUM Journal of Economics and Management, 15(2), 197-217

Zarrouk J. (2015). The role of Islamic finance in achieving sustainable development. Development Finance Agenda, 1(3), 4-5. 